\title{
KAJIAN TEORETIS INTERAKSI ANTARMOLEKUL PADA KOMPLEKS INKLUSI HIDROKSIPROPIL-ק-SIKLODEKSTRIN DAN HIDROKSIKLOROKUIN
}

\author{
ATTHAR LUQMAN IVANSYAH ${ }^{1,2 *}$ \\ ${ }^{1}$ Program Studi Magister Sains Komputasi, Fakultas Matematika dan Ilmu Pengetahuan Alam, Institut \\ Teknologi Bandung, Jalan Ganesha No. 10, Bandung, Jawa Barat, 40132 \\ ${ }^{2}$ Kelompok Keahlian Kimia Analitik, Departemen Kimia, Institut Teknologi Bandung, Jalan Ganesha No. \\ 10, Bandung, Jawa Barat, 40132
}

*alamat email korespondensi: atthar@compscience.itb.ac.id

\begin{tabular}{|c|c|}
\hline Informasi Artikel & Abstrak/Abstract \\
\hline $\begin{array}{l}\text { Riwayat Naskah : } \\
\text { Diterima pada } 03 \\
\text { November } 2020 \\
\text { Diterima setelah } \\
\text { direvisi pada } 27 \\
\text { Desember } 2020 \\
\text { Diterbitkan pada } 31 \\
\text { Desember } 2020\end{array}$ & $\begin{array}{l}\text { Di penghujung tahun } 2019 \text {, terjadi wabah dengan gejala yang mirip dengan SARS di } \\
\text { Republik Rakyat China yang disebabkan oleh virus SARS-CoV-2. Penyebaran virus } \\
\text { yang masif, termasuk di Indonesia, menyebabkan WHO mengeluarkan status pandemi. } \\
\text { Salah satu alternatif untuk mengurangi pasien COVID-19 adalah dengan menggunakan } \\
\text { obat-obatan yang ada, hingga vaksin ditemukan dan siap digunakan. Saat ini, } \\
\text { hidroksiklorokuin telah banyak diteliti sebagai kandidat obat anti COVID-19, yang kini } \\
\text { telah memasuki tahap uji klinis. Namun kelarutan hidroksiklorokuin dalam air sangat } \\
\text { kecil sehingga berdampak pada rendahnya ketersediaan hayati dalam tubuh manusia. } \\
\text { Salah satu cara untuk meningkatkan kelarutan hidroksiklorokuin dalam air adalah } \\
\text { melalui pembentukan kompleks inklusi yang stabil dengan hidroksipropil- } \beta- \\
\text { siklodekstrin. Pada penelitian ini telah dilakukan studi komputasi dengan metode } \\
\text { penambatan molekul dan metode kuantum semiempiris untuk mengetahui interaksi } \\
\text { antara hidroksipropil- } \beta \text {-siklodekstrin dan hidroksiklorokuin. Hasil studi komputasi ini } \\
\text { menunjukkan bahwa hidroksipropil- } \beta \text {-siklodekstrin dan hidroksiklorokuin membentuk } \\
\text { kompleks inklusi yang stabil. Selain itu, kelarutan hidroksiklorokuin dalam larutan air } \\
\text { dapat ditingkatkan dengan membentuk kompleks inklusi dengan hidroksipropil- } \beta- \\
\text { siklodekstrin. }\end{array}$ \\
\hline
\end{tabular}

Keywords:

Hydroxypropyl- $\beta$ -

Siklodekstrin;

At the end of 2019, there was an outbreak with symptoms similar to SARS in the People's Republic of China caused by the SARS-CoV-2 virus. The massive spread of the virus, including in Indonesia, caused WHO to issue a pandemic status. One alternative to reducing COVID-19 patients is to use existing drugs until a vaccine is found and ready Hydroxychloroquine; SARS-CoV-2; COVID19; Inclusion Complex. for use. Currently, hydroxychloroquine has been widely researched as a candidate for anti-COVID-19 drugs, which has now entered the clinical trial stage. However, the solubility of hydroxychloroquine in water is so small that it has an impact on its low bioavailability in the human body. One way to increase the solubility of hydroxychloroquine in water is through the formation of a stable inclusion complex with hydroxypropyl- $\beta$-siklodekstrin. In this research, theoretical investigation with molecular docking and semiempirical quantum method were conducted to investigate the interaction between hydroxypropyl- $\beta$-siklodekstrin and hydroxychloroquine. The results of this investigation show that hydroxypropyl- $\beta$-siklodekstrin and hydroxychloroquine form a stable inclusion complex. Also, the solubility of hydroxychloroquine in an aqueous solution can be enhanced by forming the inclusion complex with hydroxypropylBsiklodekstrin.

\section{PENDAHULUAN}

Sampai tanggal 3 November 2020, menurut situs https://www.worldometers.info/coronavirus/ yang diakses pada tanggal 3 November 2020 pukul 08.23 WIB, kasus positif penderita COVID19 di Indonesia telah mencapai 415.402 kasus dan diperkirakan data tersebut akan terus bertambah, yang mana sampai saat ini kurva pertambahan penderita COVID-19 di Indonesia masih belum mencapai puncak. Namun demikian, sampai saat ini, vaksin yang telah ditemukan masih dalam tahap uji coba sehingga belum dapat dipakai secara aman oleh manusia. Jika menunggu sampai vaksin bisa digunakan secara aman, dikhawatirkan jumlah penderita COVID-19 akan semakin bertambah. Oleh karena itu, perlu ditemukan alternatif pengganti vaksin ini. 
Salah satu alternatif yang berpotensi tinggi untuk mengurangi penderita COVID-19 adalah dengan menggunakan obat-obatan yang sudah ada. Leah Shaffer melaporkan dalam jurnal nature medicine pada tanggal 15 Mei 2020 (http://dx.doi.org/10.1038/d41591-020-00019-9) beberapa obat antivirus COVID-19 yang berpotensi tinggi untuk mengobati COVID-19, antara lain: Klorokuin, Hidroksiklorokuin, Lopinavir, Ritonavir, Nafamostat, Camostat, Famotidine, Umifenovir, Nitazoxanide, Ivermectin, Corticosteroid, Tocilizumab, Sarilumab, Bevacizumab, Fluvoxamine. Namun, beberapa obat-obatan ini memiliki kelarutan dan permeabilitas yang rendah di dalam tubuh manusia, sehingga perlu adanya solusi untuk meningkatkan kelarutan dan permeabilitas obatobatan tersebut agar dapat mengobati penderita COVID-19 secara efektif dan efisien. Salah satu solusinya adalah dengan menggunakan material penghantar obat tertarget, seperti turunan $\beta$ siklodekstrin yang terfungsionalisasi gugus fungsi organik.

$\beta$-siklodekstrin adalah senyawa organik siklik (oligosakarida siklik) dengan tujuh unit glukosa yang dihubungkan oleh ikatan $\alpha-1,4$ glikosidik. $\beta$-siklodekstrin diperoleh dari transformasi pati melalui proses enzimatik. $\beta$ siklodekstrin banyak digunakan untuk berbagai aplikasi karena kemampuannya untuk membentuk kompleks inklusi dengan berbagai molekul yang berukuran besar [1-3]. $\beta$-siklodekstrin telah digunakan oleh beberapa peneliti untuk aplikasi biomedis karena sifat toksisitasnya dan immunogenisitasnya yang rendah [4], meningkatkan kelarutan dan stabilitas obat [5], meningkatkan penyerapan obat [6], menutupi bau dan rasa [7], mengendalikan profil pelepasan obat [8], mengurangi toksisitas lokal dan sistemik [9], serta meningkatkan permeabilitas obat di seluruh penghalang sistem biologis [10].

Pada beberapa tahun terakhir, sifat fisikokimia dan kapasitas inklusi dari $\beta$ siklodekstrin asli telah ditingkatkan dengan melakukan modifikasi kimia pada gugus fungsi hidroksilnya [11]. Setiap unit glukopiranosa $\beta$ siklodekstrin memiliki 3 kelompok hidroksil reaktif dengan rasio reaktivitas dan fungsi yang berbeda, dalam kasus $\beta$-siklodekstrin dimungkinkan untuk mengubah 21 kelompok hidroksil dengan reaksi kimia atau enzimatik [12]. Turunan $\quad \beta$-siklodekstrin, biasanya, dikelompokkan berdasarkan interaksinya dengan molekul air, yaitu, turunan hidrofilik, hidrofobik atau terionisasi. Kelompok pertama (hidrofilik) memiliki kelarutan yang lebih baik dalam air dan cocok untuk pembentukan kompleks inklusi dengan molekul guest yang memiliki kelarutan buruk di dalam air. Dimetil- $\beta$-siklodekstrin, trimetil- $\beta$-siklodekstrin, $\quad \beta$-siklodekstrin terhidroksialkilasi seperti hidroksipropil- $\beta$ siklodekstrin dan $\beta$-siklodekstrin bercabang seperti glikosil- $\beta$-siklodekstrin adalah beberapa contoh turunan $\beta$-siklodekstrin hidrofilik. Turunan hidrofobik, misalnya dietil- $\beta$-siklodekstrin, mampu menurunkan dan memodulasi laju pelepasan molekul yang larut dalam air. $\beta$ siklodekstrin terionisasi seperti karboksimetil- $\beta$ siklodekstrin, karboksimetiletil- $\beta$-siklodekstrin, dan sulfobutileter- $\beta$-siklodekstrin, dapat meningkatkan laju disolusi, kapasitas inklusi dan juga penurunan efek samping dari beberapa molekul [11,13]. Hidroksipropil- $\beta$-siklodekstrin dan sulfobutileter- $\beta$-siklodekstrin adalah turunan yang paling banyak digunakan di industri farmasi, karena toksisitasnya yang rendah dan kelarutannya yang tinggi, sehingga membuatnya cocok untuk diaplikasikan sebagai obat yang diberikan secara oral $[9,13,14]$.

Dalam beberapa penelitian, turunan $\beta$ siklodekstrin telah dikombinasikan dengan obat antivirus untuk meningkatkan kinerja obat tersebut. Cavalli dkk. mengkombinasikan Acyclovir ke dalam $\beta$-siklodekstrin(4akriloilmorfolin) untuk meningkatkan aktivitas antivirus dari Acyclovir [15]; Cavalli dkk. juga telah melakukan enkapsulasi Acyclovir ke dalam siklodekstrin terkarboksilasi untuk meningkatkan aktivitas Acyclovir [16]. Asamglisirhetinat- $\beta$ siklodekstrin telah digunakan oleh Xiao dkk. sebagai agen antivirus influenza [17]. Sosnik dkk. telah berhasil mensintesis kompleks inklusi 1indanon tiosemikarbazon dan hidroksipropil- $\beta$ siklodekstrin untuk meningkatkan aktivitas 1indanon tiosemikarbazon sebagai antivirus untuk melawan virus hepatitis C (HCV) [18]. Dalam penelitian terbaru, sulfobutileter- $\beta$-siklodekstrin telah digunakan untuk meningkatkan kelarutan Remdesivir sebagai obat antivirus COVID-19 setelah kedua molekul host dan guest tersebut dikombinasikan [19].

Di sisi lain, pemodelan komputasi adalah suatu metode yang tepat untuk dapat menjelaskan fenomena mikroskopik yang terjadi pada proses pembentukan kompleks inklusi senyawa-senyawa host-guest. Melalui pemodelan komputasi, beberapa peneliti telah berhasil membuktikan kesesuaian antara hasil eksperimen dan hasil pemodelan serta dapat menjelaskan hasil eksperimen proses pembentukan kompleks inklusi antara molekul guest berupa obat-obatan dengan molekul host $\beta$-siklodekstrin.

Hidroksiklorokuin adalah obat yang digunakan untuk mencegah penyakit malaria. 
Hidroksiklorokuin juga digunakan sebagai obat anti-reumatoid untuk pengobatan RA (Rheumatoid Arthritis). Namun, sebagai obat anti-reumatoid, hidroksiklorokuin dosis tinggi diperlukan untuk pengobatan penyakit yang cepat. Hal ini diperkirakan karena kelarutan hidroksiklorokuin yang rendah dalam air. Pada tahun 2020, hidroksiklorokuin dipelajari untuk mencegah dan mengobati penyakit COVID-19, tetapi semua uji klinis yang dilakukan selama tahun 2020 terbukti tidak efektif dan dapat menyebabkan efek samping yang berbahaya. Hal ini juga bisa disebabkan oleh kelarutan hidroksiklorokuin yang rendah di dalam air. Dengan demikian, kelarutan hidroksiklorokuin di dalam air perlu ditingkatkan untuk meningkatkan kinerja hidroksiklorokuin di dalam tubuh manusia, yaitu dengan cara membentuk kompleks inklusi yang stabil dengan senyawa supramolekul organik. Salah satu senyawa supramolekul organik tersebut adalah turunan $\beta$-siklodekstrin, yaitu hidroksipropil- $\beta$ siklodekstrin. Dalam penelitian ini, telah dilakukan pemodelan komputasi menggunakan metode penambatan molekul dan kuantum semiempiris untuk mempelajari interaksi antara hidroksipropil- $\beta$-siklodekstrin dan hidroksiklorokuin di dalam kondisi vakum dan dengan adanya pelarut air.

\section{EKSPERIMEN}

Fokus dalam penelitian ini $r$ adalah
melakukan pemodelan komputasi untuk
mempelajari interaksi antarmolekul $\begin{array}{r}\text { antara } \\ \text { hidroksipropil- } \beta \text {-siklodekstrin }\end{array}$
hidroksiklorokuin di dalam kondisi vakum dan
dengan adanya pelarut air guna memperoleh
informasi mengenai kelarutan hidroksiklorokuin
di dalam air sebelum dan sesudah membentuk
kompleks inklusi dengan hidroksipropil- $\beta-$
siklodekstrin. Penjelasan detail mengenai metode
pada penelitian ini merujuk pada penelitian kami
sebelumnya.

\section{Perangkat Lunak (Software)}

Perangkat lunak yang digunakan dalam penelitian ini sama seperti perangkat lunak yang telah digunakan pada penelitian sebelumnya [2024], antara lain: Gaussian 09 Rev. D.01 [25], YASARA Structure versi 20.8.23 [26], dan Avogadro versi 1.2.0 [27].

\section{Perangkat Keras (Hardware)}

Sama seperti pada penelitian sebelumnya [20-24], perangkat keras yang digunakan dalam penelitian ini antara lain: server komputer dengan spesifikasi prosessor Intel Xeon E5-2620 v2 @ $2.10 \mathrm{GHz}$ dengan total prosessor sebanyak 24 buah, RAM 64 GB, dan HDD 500 GB.

\section{Prosedur}

Penelitian ini telah dilakukan dalam beberapa tahap. Tahap pertama adalah membuat model hidroksipropil- $\beta$-siklodekstrin (yang diberi kode HP-Cyd) sebagai molekul host dan hidroksiklorokuin (yang diberi kode Hklrkn) sebagai molekul guest dengan bantuan perangkat lunak Avogadro versi 1.2.0 [27]. HP-Cyd dibuat dengan memodifikasi struktur $\beta$-siklodekstrin, yang mana struktur molekul $\beta$-siklodekstrin diperoleh dari ccdc.cam.ac.uk dengan kode BUVSEQ02 [28]. Model $\beta$-siklodekstrin dengan kode ini telah digunakan pada beberapa penelitian sebelumnya [29-34]. Modifikasi $\beta$-siklodekstrin untuk memperoleh HP-Cyd, dilakukan dengan mengganti atom $\mathrm{H}$ pada gugus hidroksi $\mathrm{O} 6$ dengan gugus 2-hidroksipropil. O6 adalah atom oksigen yang berikatan dengan atom $\mathrm{C}$ nomor 6 pada monomer glukosa penyusun $\beta$-siklodekstrin. Model molekul guest hidroksiklorokuin diperoleh dari bank data yang diakses melalui drugbank.ca [35].

Tahap Kedua adalah penambatan molekul hidroksiklorokuin ke dalam cavity hidroksipropil$\beta$-siklodekstrin dengan menggunakan perangkat lunak Autodock VINA yang telah disatukan ke dalam perangkat lunak YASARA Structure versi 20.8.23 dan diotomatisasi dengan bantuan file macro dock_run [26]. Pada penambatan molekul ini, hidroksiklorokuin bertindak sebagai molekul ligan dan hidroksipropil- $\beta$-siklodekstrin bertindak sebagai molekul reseptor.

Tahap Ketiga adalah optimasi geometri kompleks inklusi yang diperoleh dari Tahap Kedua yang memiliki nilai energi ikatan paling positif atau dengan skor tertinggi. Optimasi geometri dilakukan dengan metode kuantum semiempiris PM3 pada kondisi vakum dan solvasi implisit (dengan metode PCM). Optimasi geometri pada tahap ini dilakukan dengan menggunakan perangkat lunak Gaussian 09 Rev. D.01 [25].

Tahap Keempat adalah melakukan analisis data hasil perhitungan yang diperoleh pada Tahap Ketiga. Analisis hasil perhitungan yang dilakukan dalam penelitian ini antara lain penentuan nilai parameter termodinamika seperti $\Delta \mathrm{E}, \Delta \mathrm{H}$, dan $\Delta \mathrm{G}$ dari hasil perhitungan pada Tahap Ketiga. 


\section{HASIL DAN PEMBAHASAN}

\section{Pemodelan Penambatan Molekul}

Dari pemodelan penambatan molekul didapatkan bahwa kompleks inklusi antara HPCyd dan Hklrkn memiliki nilai energi ikat 4,808 $\mathrm{kkal} / \mathrm{mol}$ dan nilai konstanta disosiasi 0,299 Mm. Nilai energi ikat yang positif menandakan bahwa penguraian kompleks inklusi HP-Cyd dan Hklrkn menjadi senyawa-senyawa penyusunnya membutuhkan energi sebesar 4,808 $\mathrm{kkal} / \mathrm{mol}$, yang mana mengindikasikan bahwa kompleks inklusi ini bersifat stabil. Selain itu, bagian molekul Hklrkn yang mengandung atom klorin berada di dalam rongga HP-Cyd yang terdapat atom $\mathrm{O} 2$ dan $\mathrm{O} 3$, seperti yang diperlihatkan oleh Gambar 1. $\mathrm{O} 2$ dan $\mathrm{O} 3$, secara berturut-turut adalah atom oksigen yang berikatan dengan atom C nomor 2 dan 3 pada monomer glukosa penyusun HP-Cyd. Selanjutnya, dilakukan optimasi geometri dengan metode kuantum semiempiris PM3, terhadap struktur molekul kompleks inklusi HP-Cyd dan Hklrkn hasil dari penambatan molekul yang memiliki energi ikat paling positif. Optimasi geometri ini perlu dilakukan karena penerapan metode penambatan molekul untuk memperoleh struktur kompleks inklusi HP-Cyd dan Hklrkn, menggunakan struktur HP-Cyd yang kaku sehingga akurasi nilai energi ikat antarmolekul hasil pemodelan ini 98emperat rendah. Pada optimasi geometri dengan metode kuantum semiempiris, struktur HP-Cyd dan Hklrkn dibiarkan relaksasi sampai mencapai kondisi optimum pada kondisi vakum dan di dalam pelarut air.

Hasil optimasi geometri dengan metode kuantum semiempiris PM3 mengindikasikan bahwa HP-Cyd dan Hklrkn membentuk kompleks inklusi yang stabil baik di kondisi vakum maupun di dalam pelarut air, ditandai dengan nilai energi ikat yang negatif. Semakin negatif nilai energi ikat antar molekul, hasil dari optimasi geometri dengan metode PM3, semakin stabil kompleks inklusi yang terbentuk. Namun demikian, kompleks inklusi HP-Cyd dan Hklrkn lebih stabil terbentuk di dalam pelarut air dibandingkan pada kondisi vakum, ditandai dengan nilai energi ikat antarmolekulnya yang lebih negatif di dalam pelarut air jika dibandingkan dengan di kondisi vakum, yaitu $-3,58 \mathrm{kkal} / \mathrm{mol}$ dan $-7,94 \mathrm{kkal} / \mathrm{mol}$, secara berturut-turut pada kondisi vakum dan di dalam pelarut air.

Energi ikat antarmolekul dinyatakan oleh persamaan (1).

$\Delta E=E_{\text {molekul di dalam pelarut air }}$

$E_{\text {molekul pada kondisi vakum (fasa gas) }}$

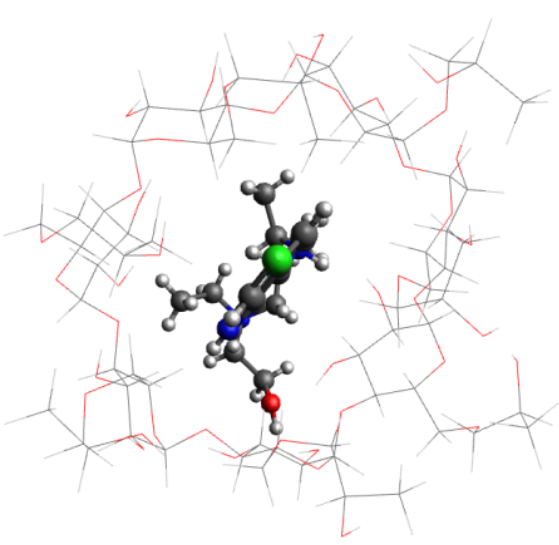

(a)

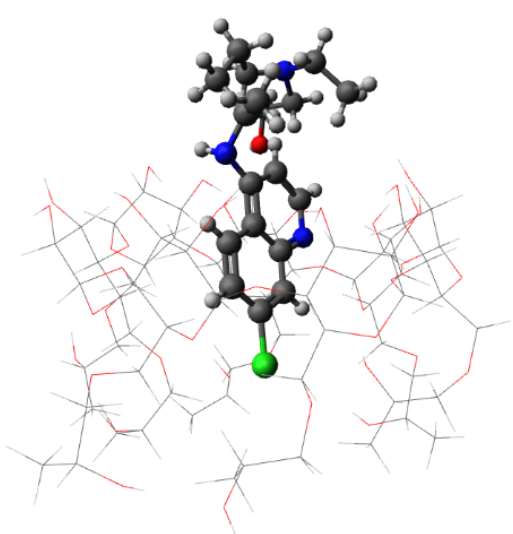

(b)

Gambar 1. Struktur molekul kompleks inklusi terbaik antara HP-Cyd dan Hklrkn dari pemodelan penambatan molekul dengan nilai energi ikat paling positif: (a) tampak atas, (b) tampak samping

\section{Optimasi Geometri dengan Metode Kuantum Semiempirik}

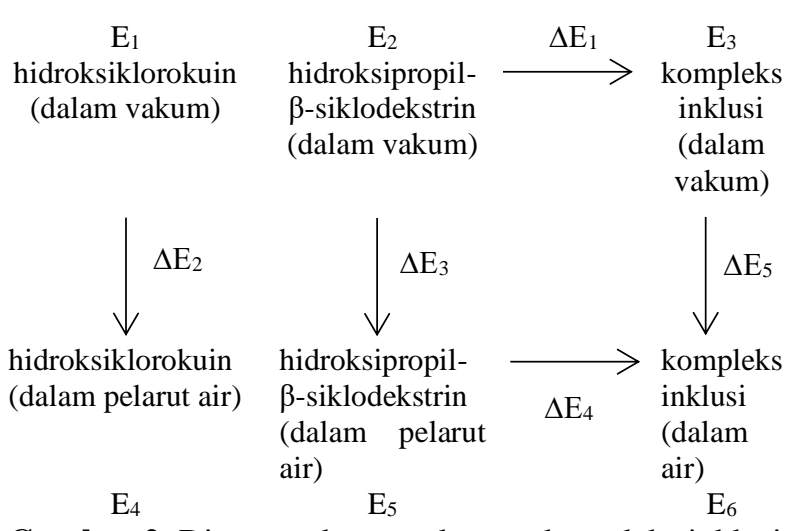

Gambar 2. Diagram skema pelarutan kompleks inklusi HP-Cyd dan Hklrkn

dimana $E_{\text {molekul di dalam pelarut air }}$ adalah energi kompleks inklusi HP-Cyd dan Hklrkn hasil optimasi dengan metode kuantum semiempiris PM3 di dalam pelarut air, sedangkan

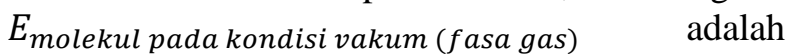
energi kompleks inklusi HP-Cyd dan Hklrkn hasil optimasi dengan metode kuantum semiempiris PM3 pada kondisi vakum atau fasa gas. 
Sama seperti pada penelitian sebelumnya [20], Skema proses pelarutan kompleks inklusi HP-Cyd dan Hklrkn diperlihatkan oleh Gambar 2. $E_{1}, E_{2}, E_{3}$, secara berturut-turut adalah energi Hklrkn, HP-Cyd, kompleks inklusi HP-Cyd dan Hklrkn pada kondisi vakum atau fasa gas. $\mathrm{E}_{4}, \mathrm{E}_{5}$, $\mathrm{E}_{6}$, secara berturut-turut adalah energi Hklrkn, HP-Cyd, kompleks inklusi HP-Cyd dan Hklrkn di dalam pelarut air.

$\Delta \mathrm{E}_{1}, \Delta \mathrm{E}_{2}, \Delta \mathrm{E}_{3}, \Delta \mathrm{E}_{4}, \Delta \mathrm{E}_{5}$ secara berturutturut adalah energi pembentukan kompleks inklusi HP-Cyd dan Hklrkn pada kondisi vakum atau fasa gas, energi pelarutan Hklrkn di dalam pelarut air, energi pelarutan HP-Cyd di dalam pelarut air, energi pembentukan kompleks inklusi HP-Cyd dan Hklrkn di dalam pelarut air, energi pelarutan kompleks inklusi HP-Cyd dan Hklrkn di dalam pelarut air, yang mana $\Delta \mathrm{E}_{1}, \Delta \mathrm{E}_{2}, \Delta \mathrm{E}_{3}, \Delta \mathrm{E}_{4}, \Delta \mathrm{E}_{5}$ masing-masing dinyatakan oleh persamaan (2), (3), (4), (5), (6).

$$
\begin{aligned}
& \Delta \mathrm{E}_{1}=\mathrm{E}_{3}-\left(\mathrm{E}_{1}+\mathrm{E}_{2}\right) \\
& \Delta \mathrm{E}_{2}=\mathrm{E}_{4}-\mathrm{E}_{1} \\
& \Delta \mathrm{E}_{3}=\mathrm{E}_{5}-\mathrm{E}_{2} \\
& \Delta \mathrm{E}_{4}=\mathrm{E}_{6}-\left(\mathrm{E}_{4}+\mathrm{E}_{5}\right) \\
& \Delta \mathrm{E}_{5}=\mathrm{E}_{6}-\mathrm{E}_{3}
\end{aligned}
$$

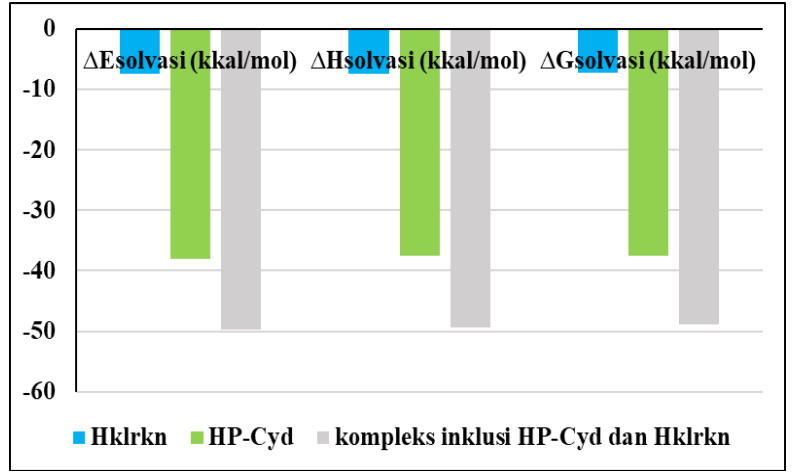

Gambar 3. $\Delta \mathrm{E}_{\text {solvasi, }} \Delta \mathrm{H}_{\text {solvasi, }}$ dan $\Delta \mathrm{G}_{\text {solvasi }}$ masingmasing untuk Hklrkn, HP-Cyd, dan kompleks inklusi HP-Cyd dan Hklrkn.

Pembentukan kompleks inklusi HP-Cyd dan Hklrkn di dalam pelarut air melepaskan energi sebesar 49,95 kkal/mol dan terjadi secara spontan ditandai dengan nilai $\Delta \mathrm{G}$ pelarutan $\left(\Delta \mathrm{G}_{\text {solvasi }}\right)$ yang negatif, yaitu sebesar $-48,90 \mathrm{kkal} / \mathrm{mol}$. Kelarutan Hklrkn dan HP-Cyd dapat ditingkatkan dengan membentuk kompleks inklusi antara keduanya, ditandai dengan nilai $\Delta \mathrm{E}_{\text {solvasi, }} \Delta \mathrm{H}_{\text {solvasi }}$, dan $\Delta \mathrm{G}_{\text {solvasi }}$ Hklrkn dan HP-Cyd dalam keadaan bebas yang lebih negatif jika dibandingkan dengan nilai $\Delta \mathrm{E}_{\text {solvasi, }} \Delta \mathrm{H}_{\text {solvasi, }}$ dan $\Delta \mathrm{G}_{\text {solvasi }}$ kompleks inklusi
Hklrkn dan HP-Cyd, seperti yang diperlihatkan oleh diagram pada Gambar 3.

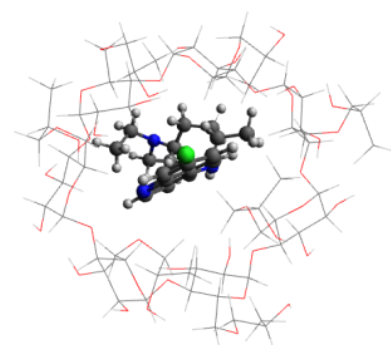

(a)

(b)

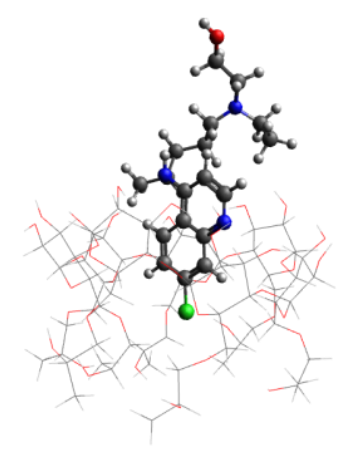

(c)
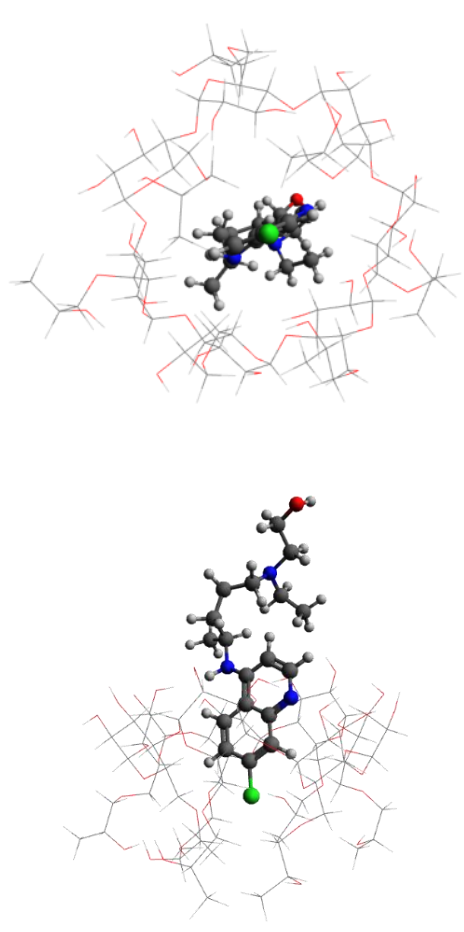

(d)

Gambar 4. Struktur teroptimasi dari kompleks inklusi HP-Cyd dan Hklrkn yang dihitung dengan metode kuantum semiempiris PM3 pada kondisi vakum (a) tampak atas, (b) tampak samping, dan di dalam pelarut air (c) tampak atas, (d) tampak samping

Hasil optimasi geometri struktur molekul kompleks inklusi HP-Cyd dan Hklrkn dengan metode kuantum semiempiris pada kondisi vakum dan di dalam pelarut air, diperlihatkan oleh 
Gambar 4. Kompleks inklusi yang dibentuk oleh HP-Cyd dan Hklrkn adalah kompleks inklusi yang stabil, dimana Hklrkn tetap berada di dalam rongga HP-Cyd setelah dilakukan optimasi geometri dengan metode kuantum semiempiris PM3 terhadap stuktur kompleks inklusi HP-Cyd dan Hklrkn hasil dari penambatan molekul.

Kelarutan kompleks inklusi juga dapat dinyatakan sebagai partisi dari kompleks inklusi antara pelar100emperanik (1-oktanol) dan pelarut air, yaitu $\mathrm{P}_{\mathrm{o} / \mathrm{w}}$, yang dinyatakan oleh persamaan (2).

$P_{o / w}=\frac{[\text { inclusion complex }]_{1-\text { oktanol }}}{[\text { inclusion complex }]_{\text {air }}}$

Kelarutan kompleks inklusi HP-Cyd dan Hklrkn dapat diprediksi dari nilai $\mathrm{P}_{\mathrm{o} / \mathrm{w}}$. Kelarutan kompleks inklusi HP-Cyd dan Hklrkn berbanding terbalik dengan nilai $\mathrm{P}_{\mathrm{o} / \mathrm{w}}$. Jika nilai $\mathrm{P}_{\mathrm{o} / \mathrm{w}}$ semakin besar, maka diprediksi kelarutan kompleks inklusi HP-Cyd dan Hklrkn di dalam air semakin kecil. Dan sebaliknya, jika nilai $\mathrm{P}_{\mathrm{o} / \mathrm{w}}$ semakin kecil, maka diprediksi kelarutan kompleks inklusi HPCyd dan Hklrkn semakin besar. Persamaan (3) sampai dengan persamaan (8) adalah penurunan untuk mendapatkan persamaan $\mathrm{P}_{\mathrm{o} / \mathrm{w}}$ Dari persamaan (8), diperoleh bahwa nilai $\mathrm{P}_{\mathrm{o} / \mathrm{w}}$ bergantung pada $\Delta \mathrm{G}$ reaksi kesetimbangan pelarutan kompleks inklusi di dalam dua fasa pelarut yaitu air dan 1-oktanol seperti yang dinyatakan oleh persamaan reaksi (3) dan bergantung pada temperatur. Pada nilai $\Delta \mathrm{G}$ yang tetap untuk reaksi pada persamaan (3), nilai $\mathrm{P}_{\mathrm{o} / \mathrm{w}}$ berbanding terbalik dengan temperatur $\mathrm{T}$. Semakin tinggi temperatur, semakin kecil nilai $\mathrm{P}_{\mathrm{o} / \mathrm{w}}$, dan kelarutan di dalam air semakin tinggi. Dan sebaliknya, semakin rendah temperatur, semakin besar nilai $\mathrm{P}_{\mathrm{o} / \mathrm{w}}$, dan kelarutan di dalam air semakin rendah.

kompleks inklusi $_{(\text {dalam pelarut air })} \rightleftharpoons$

kompleks inklusi $i_{\text {(dalam pelarut 1-oktanol) }}$

$\Delta G_{1-o k t a n o l / a i r}=$

$G_{\text {kompleks inklusi di 1-oktanol }}$

$G_{\text {kompleks inklusi di air }}$

$-R T \ln \frac{\left[{\text { kompleks inklusi }]_{1-\text { oktanol }}}_{[\text {kompleks inklusi }]_{\text {air }}}\right.}{[\text { ing }}=$

$G_{\text {kompleks inklusi di 1-oktanol- }}$

$G_{\text {kompleks inklusi di air }}$

$-R T \ln P_{o / w}=G_{\text {kompleks inklusi di 1-oktanol }}-$

$G_{\text {kompleks inklusi di air }}$ $\ln P_{o / w}=$

$-\frac{G_{\text {kompleks inklusi di 1-oktanol }}-G_{\text {kompleksinklusi diair }}}{R T}$

$P_{o / w}=$

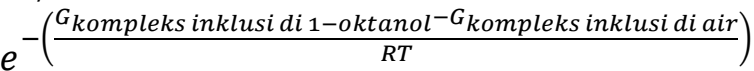

Dari hasil perhitungan dengan metode kuantum semiempiris $\mathrm{PM} 3$, diperoleh nilai $\mathrm{P}_{\mathrm{o} / \mathrm{w}}$ pada 298 K untuk Hklrkn, HP-Cyd, kompleks inklusi HP-Cyd dan Hklrkn secara berturut-turut adalah $0,108,4,469 \times 10^{-6}, 7,071 \times 10^{-12}$. Nilai $\mathrm{P}_{\mathrm{o} / \mathrm{w}}$ kompleks inklusi HP-Cyd dan Hklrkn lebih kecil jika dibandingkan dengan nilai $\mathrm{P}_{\mathrm{o} / \mathrm{w}}$ Hklrkn. Dengan demikian, dari nilai $\mathrm{P}_{\mathrm{o} / \mathrm{w}}$ ini, dapat disimpulkan bahwa kelarutan Hklrkn diprediksi meningkat ketika membentuk kompleks inklusi dengan HP-Cyd.

\section{SIMPULAN}

Dari penelitian ini dapat disimpulkan bahwa Hklrkn membentuk kompleks inklusi yang stabil dengan HP-Cyd dengan nilai energi ikat antar molekul sebesar 4,808 $\mathrm{kkal} / \mathrm{mol}$ yang diperoleh dari pemodelan penambatan molekul, $-3,58$ $\mathrm{kkal} / \mathrm{mol}$ yang diperoleh dari perhitungan kuantum semiempirik PM3 dalam kondisi vakum, dan -7,94 $\mathrm{kkal} / \mathrm{mol}$ diperoleh dari perhitungan kuantum semiempirik PM3 di dalam pelarut air. Kelarutan Hklrkn di dalam air dapat ditingkatkan dengan membentuk kompleks inklusi dengan HP-Cyd. Namun, hasil ini masih harus dikonfirmasi dengan metode yang lebih tinggi, seperti metode DFT, untuk mendapatkan hasil kalkulasi yang lebih akurat.

\section{UCAPAN TERIMA KASIH}

Penelitian ini didanai oleh Program Hibah Penelitian DIKTI pada tahun 2020 dengan nomor kontrak 2 / AMD / E1 / KP.PTNBH / 2020, yang diberikan oleh Pemerintah Indonesia melalui Kementerian Pendidikan dan Kebudayaan Republik Indonesia. Penulis juga mengucapkan terima kasih kepada Dr. Enung Siti Nurhidayah dan Suci Zulaikha Hildayani, M.Si. untuk mengumpulkan dan menganalisis data.

\section{REFERENSI}

[1] V. Sinha, R. Anitha, S. Ghosh, A. Nanda, and R. Kumria, "Complexation of celecoxib with $\beta$-cyclodextrin: Characterization of the interaction in solution and in solid state", 
Journal of Pharmaceutical Sciences, vol. 94, no. 3, pp. 676-687, 2005.

[2] C. Anselmi, M. Centini, M. Ricci, A, Buonocore, P. Granata, et al., "Analytical characterization of a ferulic acid $/ \gamma$ cyclodextrin inclusion complex", Journal of Pharmaceutical and Biomedical Analysis, vol. 40, no. 4, pp. 875-881, 2006.

[3] K.L. Yap, X. Liu, J.C. Thenmozhiyal, and P.C. Ho, "Characterization of the 13-cisretinoic acid/cyclodextrin inclusion complexes by phase solubility, photostability, physicochemical and computational analysis", European Journal of Pharmaceutical Sciences, vol. 25, no. 1, pp. 49-56, 2005.

[4] T. Irie and K. Uekama, "Pharmaceutical applications of cyclodextrins. III. Toxicological issues and safety evaluation", Journal of Pharmaceutical Sciences, vol. 86, no. 2, pp. 147-162, 1997.

[5] M.E. Brewster and T. Loftsson, "Cyclodextrins as pharmaceutical solubilizers", Advanced Drug Delivery Reviews, vol. 59, no. 7, pp. 645-666, 2007.

[6] R.L. Carrier, L.A. Miller, and I. Ahmed, "The utility of cyclodextrins for enhancing oral bioavailability", Journal of Controlled Release, vol. 123, no. 2, pp. 78-99, 2007.

[7] K. Uekama, F. Hirayama, and T. Irie, "Cyclodextrin drug carrier systems," Chem. Rev., vol. 98, no. 5, pp. 2045-2076, 1998.

[8] F. Hirayama and K. Uekama, "Cyclodextrinbased controlled drug release system", Advanced Drug Delivery Reviews, vol. 36, no. 1, pp. 125-141, 1999.

[9] M. Davis and M.E. Brewster, "Cyclodextrinbased pharmaceutics: Past, present and future", Nature Reviews Drug Discovery, vol. 3, no. 12, pp. 1023-1035, 2004.

[10] T. Loftsson and M.E. Brewster, "Pharmaceutical applications of cyclodextrins: Effects on drug permeation through biological membranes", Journal of Pharmacy and Pharmacology, vol. 63, no. 9, pp. 1119-1135, 2011.

[11] H. Matsuda and H. Arima, "Cyclodextrins in transdermal and rectal delivery", Advanced Drug Delivery Reviews, vol. 36, no. 1, pp. 81-99, 1999.

[12] J. Szejtli, "Past, present, and future of cyclodextrin research", in Pure and Applied Chemistry, vol. 76, no. 10, pp. 1825-1845, 2004.
[13] T. Loftsson and D. Duchêne, "Cyclodextrins and their pharmaceutical applications", International Journal of Pharmaceutics, vol. 329, no. 1-2, pp. 1-11, 2007.

[14] V.J. Stella and R.A. Rajewski, "Cyclodextrins: Their future in drug formulation and delivery", Pharmaceutical Research, vol. 14, no. 5. pp. 556-567, 1997.

[15] R. Cavalli, M. Donalisio, A. Civra, P. Ferruti, E. Ranucci, et al., "Enhanced antiviral activity of Acyclovir loaded into $\beta$ cyclodextrin-poly(4-acryloylmorpholine) conjugate nanoparticles", Journal of Controlled Release, vol. 137, no. 2, pp. 116122, 2009.

[16] D. Lembo, S, Swaminathan, M. Donalosio, A. Civra, L. Pastero, et al., "Encapsulation of Acyclovir in new carboxylated cyclodextrinbased nanosponges improves the agent's antiviral efficacy", International Journal of Pharmaceutics, vol. 443, no. 1-2, pp. 262272, 2013.

[17] S. Liang, M. Li, X. Yu, H. Jin, Y. Zhang, et al., "Synthesis and structure-activity relationship studies of water-soluble $\beta$ cyclodextrin-glycyrrhetinic acid conjugates as potential anti-influenza virus agents", European Journal of Medicinal Chemistry, vol. 166, pp. 328-338, 2019.

[18] R.J. Glisoni, M.L. Cuestas, V.L. Mathet, J.R. Oubiña, A.G. Moglioni, and A. Sosnik, "Antiviral activity against the hepatitis C virus (HCV) of 1-indanone thiosemicarbazones and their inclusion complexes with hydroxypropyl- $\beta$ cyclodextrin", European journal of pharmaceutical sciences, vol. 47, no. 3, pp. 596-603, 2012.

[19] S.C.J. Jorgensen, R. Kebriaei, and L.D. Dresser, "Remdesivir: Review of Pharmacology, Pre-clinical Data, and Emerging Clinical Experience for COVID19", Pharmacotherapy: The Journal of Human Pharmacology and Drug Therapy, vol. 40, no. 7, pp.24-29, 2020.

[20] A.L. Ivansyah, "Investigasi Teoretis Interaksi Nonkovalen antara $\beta$-Siklodekstrin dan Hidroksiklorokuin," Akta Kimia Indonesia, vol. 5, no. 2, pp. 127-140, 2020.

[21] S. Setiadji, C.D.D. Sundari, M.A. Ramdhani, A.B.K. Umam, and A.L. Ivansyah, "Theoretical Investigation of Inclusion Complex between Omeprazole Enantiomers and Carboxymethyl- $\beta$-Cyclodextrin", in IOP Conference Series: Materials Science and 
Engineering, vol. 288, no. 1, p. 012138, 2018.

[22] A.L. Ivansyah, E.S. Nurhidayah, C.D.D. Sundari, M.A. Martoprawiro, and B. Buchari, "Computational study of inclusion complex between Omeprazole enantiomer and $\beta$ Cyclodextrin: NBO and RDG analysis", Journal of Physics: Conference Series, vol. 1402, no. 5, 2019.

[23] S. Setiadji, C.D.D. Sundari, B.W. Nuryadin, H. Zayyinunnisya, R. Cahyandari, and A.L. Ivansyah, "Computational Study of Inclusion Complexes between Omeprazole Enantiomer with Hydroxypropyl- $\beta$-Cyclodextrin", Journal of Physics: Conference Series, vol. 1090, no. 1, 2018.

[24] A.L. Ivansyah, M.A. Martoprawiro, and Buchari, "Computational modeling of inclusion complex of $\mathrm{r} / \mathrm{s}$-omeprazole with $\beta$ cyclodextrin using oniom2 method", in Journal of Physics: Conference Series, vol. 812, no. 1, 2017.

[25] Gaussian 09, Revision D.01, M. J. Frisch, G. W. Trucks, H. B. Schlegel, G.E. Scuseria, M.A. Robb et al., Gaussian, Inc., Wallingford CT, 2016.

[26] E. Krieger and G. Vriend, "New ways to boost molecular dynamics simulations", Journal of Computational Chemistry, vol. 36, no. 13, pp. 996-1007, 2015.

[27] M.D. Hanwell, D.E. Curtis, D.C. Lonie, T. Vandermeerschd, E. Zurek, and G.R. Hutchison, "Avogadro: An advanced semantic chemical editor, visualization, and analysis platform", Journal of Cheminformatics, vol. 4, no. 8, p. 17, 2012.

[28] C. Betzel, W. Saenger, B.E. Hingerty, and G.M. Brown, "Circular and Flip-Flop Hydrogen Bonding in $\beta$-Cyclodextrin Undecahydrate: A Neutron Diffraction Study", Journal of the American Chemical Society, vol. 106, no. 24, pp. 7545-7557, 1984.

[29] I. Andreadelis, M.V. Chatziathanasiadou, D. Ntountaniotis, G. Valsami, C. Papaemmanouil, et al., "Charting the structural and thermodynamic determinants in phenolic acid natural product cyclodextrin encapsulations", Journal of Biomolecular Structure and Dynamics, pp. 117, 2020.
[30] T.F. Kellici, M. Chatziathanasiadou, D. Diamantis, A.V. Chatzikonstantinou, I, Andreadelis, et al., "Mapping the interactions and bioactivity of quercetin-(2hydroxypropyl)- $\beta$-cyclodextrin complex", International Journal of Pharmaceutics, vol. 511, no. 1, pp. 303-311, 2016.

[31] D. Ntountaniotis, I. Andreadellis, T. Kellici, V. Karageorgos, G. Leonis, E. Christodoulou, et al., "Host-Guest Interactions between Candesartan and Its Prodrug Candesartan Cilexetil in Complex with 2-Hydroxypropyl$\beta$-cyclodextrin: On the Biological Potency for Angiotensin II Antagonism", Molecular Pharmaceutics, vol. 16, no. 3, pp. 12551271, 2019.

[32] T.F. Kellici, D. Ntountaniotis, G. Leonis, M. Chatziathanasiadou,

A.V. Chatzikonstantinou, et al., "Investigation of the interactions of silibinin with 2hydroxypropyl- $\beta$-cyclodextrin through biophysical techniques and computational methods", Molecular Pharmaceutics, vol. 12, no. 3, pp. 954-965, 2015.

[33] G.G. Kordopati, T.V. Tselios, T. Kellici, F. Merzel, T. Mavromoustakos, et al., "A novel synthetic luteinizing hormone-releasing hormone (LHRH) analogue coupled with modified $\beta$-cyclodextrin: Insight into its intramolecular interactions", Biochimica et Biophysica Acta (BBA) - General Subjects, vol. 1850, no. 1, pp. 159-168, 2015.

[34] G. Leonis, E. Christodoulou, D. Ntountaniotis, M. Chatziathanasiadou, T. Mavromoustakos, et al., "Antihypertensive activity and molecular interactions of irbesartan in complex with 2-hydroxypropyl$\beta$-cyclodextrin," Chemical Biology and Drug Design, vol. 96, no. 1, pp. 668-683, 2020.

[35] https://go.drugbank.com/drugs/DB01611. Accessed November 3, 2020. 